\title{
The Impact of Marketing-Like-Approach to Medical Specialist's Decision for Giving Patient Recommendation to Palliative Care Unitin Haaj General Hospital Surabaya
}

\author{
Putu Ayu Dhana Reswari*1,2 \\ ${ }^{1}$ Medical faculty of Uniersitas Dr.Soetomo Surabaya \\ ${ }^{2}$ Patient Safety and Quality Committe of Haji Hospital \\ *ayu.ardhanareswari@gmail.com
}

\begin{abstract}
The number of patients who receive palliative care in Haaj General Hospital Surabaya increasing trend in 2012-2014 with an average increase of 13.5\%. Although it has experienced a significant increase in numbers, the amount is still not able to meet the target of palliative care as proposed by Gomez-Batiste et al (2005) that is equal to 75\% of total deaths. An objective of this study is to analyze the influence of marketing- like-approach and specialist psychological factors on the decision to send the patient to the Palliative Care Unit at Haaj General Hospital Surabaya. This study is observational-analytic. Samples taken were specialist who can send patients to the Palliative Care Unit in Haaj General Hospital. Determination of sampling is the stratified sampling method. The data analysis was done analytically by binary logistic regression. The results showed that psychological factors have no influence on the decision of sending patients to the Palliative Care Unit in Haaj General Hospital Surabaya. This research suggested Haaj General Hospital to resocializing against sending patients to the Palliative Care Unit in Haaj General Hospital Surabaya, held a question and answer session at the time resocializing, and considering a strategic placement for promotional media which easily seen by a specialist.
\end{abstract}

Keywords: Psychological Factors, Medical Specialists Decision, Palliative Care Unit 


\section{STRADA Jurnal Ilmiah Kesehatan}

DOI: $10.30994 /$ sjik.v9i2.503

ISSN: 2252-3847 (print); 2614-350X (online)

Vol.9 No.2 November 2020 Page. 1588-1594

\section{BACKGROUND}

Haaj General Hospital Surabaya formed Palliative Care Unit that was established in October 2009. The services provided by the Unit for Palliative Care includes outpatient services, inpatient and homecare. Given palliative care is an integrated care system aimed at improving the quality of life, by way of easing the pain and suffering of others, providing spiritual support and psychosocial started when the diagnosis is established until the end of life and support to the bereaved families and the bereaved.

The number of patients who receive palliative care in Haaj General Hospital Surabaya increasing trend in 2012-2014 with an average increase of $13.5 \%$. Although it has experienced a significant increase in numbers, the amount is still not able to meet the target of palliative care as proposed by Gomez-Batiste et al (2005) that is equal $75 \%$ of total deaths.

\section{METHODS}

This study aims to: 1) Analyzing the psychology factors of medical specialists at Haaj General Hospital, which includes personality, motivation, learning, perception and attitude, 2) Analyze the influence of psychological factors on the decision to send medical specialists to patients in the Palliative Care Unit in Haaj General Hospital.

This study is observational-analytic. Observational because researchers only make observations and measurements without any interventions or treatments in the study sample. Is said to be analytic because in analyzing the variables of the study conducted using statistical tests. When viewed in terms of time of the study, a kind of cross sectional studies because the data taken at the same time.

The population in this study are all specialist doctors can send patients to the palliative care unit and pain free in Haaj General Hospital. Samples taken were medical specialist can send patients to the palliative care unit in Haaj General Hospital. Determination of sampling is the stratified sampling method which is a method to take samples by dividing the population by class strata. Samples will be determined by random events in each group medical specialist and correctness of the data, analyze each variable in the distribution of frequencies and insert in cross table to be analyzed by binary logistic regression statistical tests.

\section{RESULT}

\section{Analyzing the psychology factors of medical specialists at Haaj General Hospital}

\section{a. Personality}

Table.1 Distribution of specialist doctors based on extroversion aspect towards the Palliative and Pain Free Care Unit at the General Hospital of Haji Surabaya in 2015

\begin{tabular}{llccccr}
\hline No & \multicolumn{1}{c}{ Question } & 1 & 2 & 3 & 4 & Total \\
\hline A. & Extroversion & & & & & \\
\hline 1. & $\begin{array}{l}\text { Explain palliative and pain-free treatment } \\
\text { and its benefits for patient recovery }\end{array}$ & 0 & 6 & 19 & 3 & 28 \\
& $\begin{array}{l}\text { Maintain communication with peers and } \\
\text { other staff in the palliative and pain-free } \\
\text { care unit. }\end{array}$ & 0 & 2 & 24 & 2 & 28 \\
\hline 2. & $0 \%$ & $7,1 \%$ & $85,7 \%$ & $7,1 \%$ & $100 \%$ \\
\hline $\begin{array}{l}\text { Tend to encourage patients to get palliative } \\
\text { and pain-free care. }\end{array}$ & 0 & 9 & 17 & 2 & 28 \\
& & $0 \% 32,1 \%$ & $60,7 \%$ & $7,1 \%$ & $100 \%$ \\
\end{tabular}




\section{STRADA Jurnal Ilmiah Kesehatan}

DOI: $10.30994 /$ sjik.v9i2.503

ISSN: 2252-3847 (print); 2614-350X (online)

Vol.9 No.2 November 2020 Page. 1588-1594

$\begin{array}{lllllll}\text { 4. } & \text { Advise other colleagues to send patients to } & 0 & 7 & 19 & 2 & 28\end{array}$

a palliative and pain-free unit of care.

$\begin{array}{lllll}0 \% & 25 \% & 67,9 \% & 7,1 \% & 100 \%\end{array}$

Table. 1.2 Specialist doctor personality category based on the extroversion aspect of sending patients to the Palliative and Pain Free Care Unit at the Surabaya Hajj General Hospital in 2015

\begin{tabular}{|c|c|c|}
\hline Kategori & Frekuensi & Persentase \\
\hline Very low & 0 & 0 \\
\hline Low & 7 & 25 \\
\hline Hight & 19 & 67,9 \\
\hline Very hight & 2 & 7,1 \\
\hline Total & 28 & 100 \\
\hline
\end{tabular}

b. Motivation

Table 1.3 Distribution of specialists' motivation based on aspects of achievement for the Palliative and Pain Free Care Unit at the General Hospital of Haji Surabaya in 2015

\begin{tabular}{llllllr}
\hline No & \multicolumn{1}{c}{ Statement } & 1 & 2 & 3 & 4 & Total \\
\hline A. & Need of Achievement & & & & & \\
\hline 1. & Trying earnestly to improve & 0 & 8 & 18 & 2 & 28
\end{tabular}

performance in sending patients to a

palliative and pain-free unit of care.

2. It is considered a challenge to undertake $\quad \begin{array}{lllll}0 & 15 & 12 & 1 & 28\end{array}$ joint care procedures with a palliative and pain-free unit of care.

3. Being curious about how progress can be made towards the patient's condition by sending the patient to a palliative and

\begin{tabular}{llcccc} 
& pain-free unit. & $0 \%$ & $25 \% 67,9 \%$ & $7,1 \%$ & $100 \%$ \\
\hline $4 . \quad$ Has its own satisfaction if it can send & 0 & 8 & 19 & 1 & 28
\end{tabular} patients who need treatment to a palliative and pain-free care unit.

\begin{tabular}{ccccc}
$0 \% 53,6 \%$ & $42,9 \%$ & $3,6 \%$ & $100 \%$ \\
\hline 0 & 7 & 19 & 2 & 28
\end{tabular}

\begin{tabular}{ccccc}
$0 \%$ & $25 \% 67,9 \%$ & $7,1 \%$ & $100 \%$ \\
\hline 0 & 8 & 19 & 1 & 28
\end{tabular}

$0 \% 28,6 \% 67,9 \% \quad 3,6 \% \quad 100 \%$

Table 1.4 The category of specialist doctor motivation based on the aspect of need of achievement for the Palliative and Pain Free Care Unit at the Surabaya Hajj General Hospital in 2015

\begin{tabular}{lrrr}
\hline & Category & Frekuensi & Persentase \\
\hline Very low & 0 & 0 \\
\hline Low & 8 & 28,6 \\
\hline Hight & 18 & 64,3 \\
\hline Very Hight & 2 & 7,1 \\
\hline Total & 28 & 100 \\
\hline
\end{tabular}




\section{STRADA Jurnal Ilmiah Kesehatan}

DOI: $10.30994 /$ sjik.v9i2.503

ISSN: 2252-3847 (print); 2614-350X (online)

Vol.9 No.2 November 2020 Page. 1588-1594

\section{c. Learning}

Table 1.5 Distribution of specialist doctor learning to the Palliative and Pain Free Care Unit through audiovisual media such as advertisements in $\mathbf{2 0 1 5}$

No Learning about the Palliative and Pain Free Care Frekuensi Persentase Unit through audiovisual media such as advertising

\begin{tabular}{llrr}
\hline 1. & Absolutely never done & 1 & 3,6 \\
\hline 2. & Almost never done & 25 & 89,3 \\
\hline 3. & Never done & 2 & 7,1 \\
\hline 4. & Often done & 0 & 0 \\
\hline & & 28 & 100 \\
\hline
\end{tabular}

\section{d. Perception}

Table 1.6 Distribution of specialist doctors' perceptions of increased knowledge and skills in treating patients with chronic diseases in 2015

No Specialist doctors' perceptions of increasing Frekuensi Persentase knowledge and skills in treating patients with

chronic diseases

\begin{tabular}{llrrr}
\hline 1. & Strongly Disagree & 0 & 0 \\
\hline 2. & Disagree & 18 & 64,3 \\
\hline 3. & Agree & 9 & 32,1 \\
\hline 4. & Very agree & 1 & 3,6 \\
\hline & & Total & 28 & 100 \\
\hline
\end{tabular}

e. Table 1.7 Distribution of specialist doctors' attitudes towards sending patients

to the Palliative and Pain-Free Care Unit at the Surabaya Hajj General Hospital in 2015

\begin{tabular}{|c|c|c|c|c|c|c|}
\hline No & Statrment & 1 & 2 & 3 & 4 & Total \\
\hline A. & Kognisi & & & & & \\
\hline \multirow[t]{2}{*}{1.} & Feeling that paying attention to & 0 & 0 & 21 & 7 & 28 \\
\hline & & $0 \%$ & $0 \%$ & $75 \%$ & $25 \%$ & $100 \%$ \\
\hline B. & Afeksi & & & & & \\
\hline 1. & $\begin{array}{l}\text { Feel happy if you have patients who can } \\
\text { be sent to the Palliative and Pain Free } \\
\text { Care Unit at the General Hospital of } \\
\text { Haii Surabava }\end{array}$ & 0 & $43 \%$ & 22 & 2 & 28 \\
\hline C. & Konasi & & & & $1,1 \%$ & $100 \%$ \\
\hline \multirow[t]{2}{*}{1.} & $\begin{array}{l}\text { Has a tendency to send patients to the } \\
\text { Palliative and Pain Free Care Unit of the } \\
\text { General Hospital of Haji Surabaya }\end{array}$ & 0 & 17 & 9 & 2 & 28 \\
\hline & & \multicolumn{3}{|c|}{$0 \% 60,7 \% 32,1 \%$} & $7,1 \%$ & $100 \%$ \\
\hline
\end{tabular}

\section{DISCUSSION}

The results showed that psychological factors have no influence on the decision of sending patients to the Palliative Care Unit in Haaj General Hospital Surabaya.

This research suggested haaj general hospital to resocializing against sending patients to the Palliative Care Unit in Haaj General Hospital Surabaya.The important thing to say is 


\section{STRADA Jurnal Ilmiah Kesehatan}

DOI: $10.30994 /$ sjik.v9i2.503

ISSN: 2252-3847 (print); 2614-350X (online)

Vol.9 No.2 November 2020 Page. 1588-1594

the benefits and procedures for sending patients to the Unit Palliative Haaj General Hospital Surabaya, held a question and answer session at the time resocializing, to know the difficulties and obstacles that may be encountered by a specialist at the time of carrying out the procedure for sending patients Unit for Palliative Care in Haaj General Hospital Surabaya, placement of promotional media in a strategic location and is easily seen by a specialist. Print media such as brochures and leaflets can be put in the installation of outpatient and inpatient at the hospital. Audiovisual impressions can be played while waiting for the start of the briefing or meeting.

\section{CONCLUSION}

Types of services and human resources in the Palliative and Pain-Free Care Unit at the General Hospital of Haji Surabaya are in accordance with the Decree of the Minister of Health of the Republic of Indonesia No. 812 / Menkes / SK / VII / 2007 regarding Palliative Care Policy. However, the target of palliative and pain-free care has so far been limited to cancer cases.

The description of the personality of a specialist doctor on sending patients to the Palliative and Pain Free Care Unit at the General Hospital of Haji Surabaya is:

The extroversion aspect of the specialist doctor's personality is high. However, there are still $25 \%$ of specialist doctors who have low extroversion aspects. The emotional stability aspect of the specialist doctor's personality is high. The agreeableness aspect of the specialist doctor's personality is high. However, there are still $21.4 \%$ of specialist doctors who have relatively low extroversion aspects. The conscientiousness aspect of the specialist's personality is high. Aspects of openness to experience in the personality of these particular doctors are high.

An overview of the specialists' motivations for sending patients to the Palliative and Pain Free Care Unit at the General Hospital of Haji Surabaya, namely: Aspects of the need for achievement of a specialist doctor's personality are high. However, there are still $28.6 \%$ of specialist doctors who have a low need for achievement aspect. The aspect of needed power in the personality of a specialist is still low. Aspects needed for affiliation in the personality of a specialist is high

Specialists still lack learning about sending patients to the Palliative and Pain Free Care Unit at the General Hospital of Haji Surabaya

Specialists have a good perception of sending patients to the Palliative and Pain-Free Care Unit at the General Hospital of Haji Surabaya. However, there are still $28.6 \%$ of specialist doctors who have a poor perception

Specialists have a strong attitude towards sending patients to the Palliative and Pain-Free Care Unit at the General Hospital of Haji Surabaya.

There is no influence on the level of psychological actor specialist doctors on the decision to send patients to the Palliative and Pain Free Care Unit at the General Hospital of Haji Surabaya.

\section{REFERENCES}

Ahmed, P.K., \& Rafiq, M. (2002). Internal Marketing : Tools and Concepts for Customer-focused Management. Oxford: Butterworth-Heinemann.

Ambler, T., \& Kokkinaki, F. (1997). Measures of Marketing Success. New York: The Dryden Press.

As'ad, M. (2001). Seri Ilmu SDM; Psikologi Industri. Yogyakarta: Liberty. Asperula, W. (2004). Standards for Providing Quality Palliative Care for

all 


\section{STRADA Jurnal Ilmiah Kesehatan}

DOI: $10.30994 /$ sjik.v9i2.503

ISSN: 2252-3847 (print); 2614-350X (online)

Vol.9 No.2 November 2020 Page. 1588-1594

Australians. Melbourne: Palliative Care Australia.

Assauri. (1999). Manajemen Pemasaran. Jakarta: Raja Grafindo Persada. Ballantyne, D.

(2000). The Strengths and Weakness of Internal Marketing.

London: Routledge.

Bambang, W. (2002). Manajemen Sumber Daya Manusia. Bandung: Sulita. Cahill, D.J. (1996). Internal Marketing : Your Company's Next Stage of Growth.

New York: The Haworth Press, Inc.

Cooper, J., \& Cronin, J.C. (2000). How to Improve Service Quality; Internal Marketing as A Determining Factor. New York: The Dryden Press.

Doyle, H., \& Macdonald. (2003). Oxford Textbook of Palliative Medicine. Oxford: Medical.

Fang, Y., \& Tang, T. (2008). How to Improve Service Quality: Internal Marketing as A Determining Factor. London: Routledge.

Ferrell, B.R. \& Coyle, N. (2007). Textbook of Palliative Nursing, $2^{\text {nd }}$ ed. New York: Oxford University Press.

Gomez-Batiste X., Martinez-Munoz M., Blay C., et. al. Identifying Needs And Improving Palliative Care of Chronically Ill Patients: A Comunity-Oriented, Population-Based, Public Health Approach. Curr Opin Support Palliative Care 2012; 6(3): 371-378.

Gounaris, S. (2006). Internal Market Orientation and Its Measurement. New York: Elsevier Science Inc.

KEPMENKES RI NOMOR: 812/ MENKES/SK/VII/2007. Kebijakan Perawatan Paliatif. Jakarta.

Kotler, K. (2007). Manajemen Pemasaran. Jakarta: PT Indeks.

Kotler, P. (2000). Manajemen Pemasaran. Edisi Milenium. Jakarta: Prehallindo. Kotler, P. (2009). Manajemen Pemasaran. Edisi 13. Jakarta: Erlangga.

Lovelock, C., \& Wirtz, J. (2004). "Services Marketing”. Fifth Edition. New Jersey: Prentice Hall.

Mangkunegara, A.P. (2005). Manajemen Sumber Daya Manusia Perusahaan. Bandung: PT Remaja Rosdakarya.

Mathis, R.L., \& Jackson, J.H. (2006). Human Resource Management. Jakarta: Salemba Empat.

Rivai, V., \& Sagala, E.J. (2009). Manajemen Sumber Daya Manusia untuk Perusahaan. Jakarta: PT Raja Grafindo Persada.

Schiffman, L.G., \& Kanuk L.L. (2008). Perilaku Konsumen. Jakarta: Indeks. Sedarmayanti. (2000). Tata Kerja dan Produktivitas Kerja (Suatu Tinjauan dari

Aspek Ergonomi atau Kaitan Antara Manusia dengan Lingkungan Kerja). Bandung: CV Mandar Maju.

Simamora, H. (2004). Manajemen Sumber Daya Manusia. Yogyakarta: STIE. Sofyandi, H. (2008). Manajemen Sumber Daya Manusia. Yogyakarta: Graha Ilmu.

Sugiarto., S, \& O. (2003). Teknik Sampling. Jakarta: Gramedia Pustaka Utama. Suminar, Y.R. (2003). Komunikasi Organisasi. Jakarta: Pusat Penerbitan Universitas Terbuka.

Sunarto. (2006). Manajemen Pemasaran 2. Yogyakarta: Adityamedia.

Suprihanto. (2001). Penilaian Kinerja dan Pengembangan Karyawan. Yogyakarta: BPPE.

Teguh, A., \& Rosidah. (2003). Manajemen Sumber Daya Manusia Konsep, Teori dan Pengembangan Dalam Konteks Organisasi Publik. Yogyakarta: Graha Ilmu

Tjiptono, F., \& Chandra, G. (2008). Pemasaran Strategik. Yogyakarta: Andi.

Tjiptono, F. (2002). Strategi Pemasaran. Yogyakarta: Andi. 


\section{STRADA Jurnal Ilmiah Kesehatan}

DOI: $10.30994 /$ sjik.v9i2.503

ISSN: 2252-3847 (print); 2614-350X (online)

Vol.9 No.2 November 2020 Page. 1588-1594

Usman, H., \& Setiady, R.P. (2000). Pengantar Statistika. Jakarta: Gramedia Pustaka Utama.

Varey, R.J., \& Barbara R.L. (2000). Internal Marketing: Tools and Concepts for Customer-focused Management. London: Routledge.

Yuwono, I. (2005). Psikologi Industri dan Organisasi. Surabaya: Fakultas Psikologi Universitas Airlangga.

Zeithaml, V., \& Bitner, M. (2003). Service Marketing. New York: The McGraw- Hill 